\title{
Why PAIN??? Do we Land-up with Pain in any Time in a Day? When and where? Why?
}

\author{
*Shahil Patel \\ Consultant Pain Management, The Pain Clinic, India
}

Submission: August 28, 2017; Published: August 30, 2017

*Corresponding author: Shahil Patel, Consultant Pain Management, The Pain Clinic, Ahmedabad, Gujarat, India, Tel: +91-9824213699;

Email: sahilp2004@gmail.com

\section{Don't we understand pain?}

Most of us are having trouble like pain either at the starting of our day while wake-up from bed either due to lack of sleep/ inadequate diet and water etc. or at the end of our work while moving from office and/ or at the home after having terrible work at home as compare to office work. Common problem his Headache and heaviness at the end of work due to exhaustion. It's a muscle which gets loosened in particulars plays. Second most problem is joint pain, leg pain, calf pain, ankle tingling.

Why it is so?

Every joint is having good blood supply and, or the nutrition it varies from different individuals and it is mostly a Degenerative. One can surely stop Degeneration if understand it. Diet is a major role to play. Water is second large concern behind Degeneration. Back pain is also a major problem in today's world; every third individual suffers from back pain. And most of this is due to very bad posture of the body and its movement and so it is physiological. It is corrected at the beginning, if not considered it can be a bad pathology. And it is surely require some intervention. Cervical neck pain is third largest concern today. Most of the youngsters are having this upper neck and head problem because of mobile, computer, etc. Longtime usage of both of this lead to burning of eyes as well as neck pain and headache and often it is associated with knee pain and lower back pain.

Majority of young persons are having trouble like this due to digital technology and it should be corrected in a proper time. Initially all these problems are treated by family physician and orthopedician and last them go to Pain Physician. Most of the time family physician will guide them on telephone and give them pain killer medicine or the person himself take the medicine from medical store randomly, if they feel little ok they do not want to go to physician. By this time our body tissue, neurovascular bundle gets damaged by our body activity and finally it get trapped by surrounding tissue, muscle, fascia, etc. Rare option left for further treatment of pain.

i. Now what next?

ii. Where to go?

iii. Whom to meet?

iv. How much time should spend for this?

So many questions are in mind and /or other side so much work has to be done. This time is very crucial for them and finally they land-up with an operative intervention. Majority of joint replacement surgeries, spine surgeries are not successful all the time in different individuals because person themselves damage their own body structure by not understanding the value of the same. In today's time most of the person is having deficiency of Vitamin B12 and Vitamin D3 and this people are consuming lot of medicine without knowing the facts that this both are available free from the nature and food. Stiffness of the joint and back while wake up from the bed suggest lack of Vitamin B12 and Vitamin D3. If you have any questions, please email, its a paid service for treatment. 
This work is licensed under Creative Commons Attribution 4.0 License DOI: 10.19080/OROAJ.2017.08.555737

\section{Your next submission with Juniper Publishers will reach you the below assets}

- Quality Editorial service

- Swift Peer Review

- Reprints availability

- E-prints Service

- Manuscript Podcast for convenient understanding

- Global attainment for your research

- Manuscript accessibility in different formats ( Pdf, E-pub, Full Text, Audio)

- Unceasing customer service

Track the below URL for one-step submission https://juniperpublishers.com/online-submission.php 